\title{
Upaya Meningkatkan Kemampuan Pengambilan Keputusan Karir Melalui Layanan Bimbingan Kelompok
}

\author{
Diana Dewi W \\ Universitas Tunas Pembangunan Surakarta, Indonesia \\ dianadewi_81@yahoo.com \\ Syahri Alhusin \\ Universitas Tunas Pembangunan Surakarta, Indonesia \\ syahri_pancoari@yahoo.co.id
}

\begin{abstract}
Abstrak
Masih banyak siswa SMK yang belom mampu melakukan pengambilan keputusan karir dikarenakan, antara lain: ragu, bimbang dan merasa tidak mantap dengan keputusan yang diambil, gagal mengambil keputusan, pilihan yang dihasilkan bukanlah pilihan yang bijak, masih memiliki ketergantungan terhadap orang lain (guru, orang tua atau teman), tidak memiliki piihan karir yang mantap, dan beberapa siswa mengatakan sudah mantap dengan pilihan karirnya tetapi masih meminta bimbingan pada pihak lain. Berdasarkan hasil multi stage cluster random sampling, yang dilakukan kepada siswa kelas XI maka didapat 10 orang siswa yang memiliki kemampuan pengambilan keputusan karir terendah. Dengan metode penelitian eksperimen menggunakan desain one grup pretest-posttest desaign maka didapat hasil peningkatan pada subjek penelitian. Dengan diberikan bimbingan kelompok dengan teknik diskusi memberikan dampak positif kepada siswa, terlihat dari sikap subjek yang mampu memberikan argument tentang rencana masa depannya setelah melihat hasil tes minat jabatan.
\end{abstract}

Kata Kunci : Layanan, Bimbingan Kelompok, Pengambilan Keputusan, Karir 


\begin{abstract}
There are still many vocational students who have not been able to make career decisions because, among others: doubt, doubt and feel uneasy about the decisions taken, fail to make decisions, the choices made are not wise choices, still have dependency on others (teachers, people parents or friends), do not have a solid career choice, and some students say they are confident in their career choices but still seek guidance from others. Based on the results of the multi-stage cluster random sampling, which was conducted on 10th grade students, 10 students had the lowest career decision-making abilities. With the experimental research method using the design of one group pretestposttest desaign, the results obtained increase in research subjects. Given group guidance with discussion techniques have a positive impact on students, it can be seen from the attitude of the subject who is able to provide arguments about his future plans after seeing the results of the position interest test.
\end{abstract}

Keywords: Service, Group Guidance, Decision Making, Career

\title{
A. Latar Belakang
}

Setiap tahun banyak siswa SMK dihadapkan dengan masalah memilih jurusan studi lanjut atau pilihan penentuan pekerjaan. Keputusan studi lanjut atau menentukan pilihan pekerjaan merupakan proses pengambilan keputusan yang rumit bagi siswa SMK. Siswa SMK merupakan remaja yang dihadapkan pada tugastugas atau kegiatan-kegiatan penentuan karir seperti: mengeksplorasi berbagai alternative pilihan pekerjaan atau studi lanjut, mengenali diri terkait minat dan keterampilan yang dimiliki, membandingkan alternative keputusan karir yang sesuai dan memilih satu opsi pada pilihan yang ada. Pada fase perkembangannya siswa SMK memiliki tugas yang harus diselesaikannya, salah satunya adalah memilih dan mempersiapkan karir dan pekerjaan melalui perencanaan masa depan karirnya.

Melalui beberapa hasil pengamatan didapat hasil masih banyak siswa SMK yang belom mampu melakukan pengambilan keputusan karir dikarenakan, antara lain: ragu, bimbang dan merasa tidak mantap dengan keputusan yang diambil, gagal mengambil keputusan, pilihan yang dihasilkan bukanlah pilihan yang bijak, masih memiliki ketergantungan terhadap orang lain (guru, orang tua atau teman), tidak memiliki piihan karir yang mantap, dan beberapa siswa mengatakan sudah mantap dengan pilihan karirnya tetapi masih meminta bimbingan pada pihak lain. 
Kemampuan siswa SMK dalam mengambil keputusan karir pastinya didasarkan pada informasi dan pemahaman pilihan karir yang dimiliki olehnya. Sebagai proses pencarian informasi atau pilihan karir, eksplorasi merupakan upaya untuk mencari informasi tentang karakteristik diri yang berkaitan dengan kelemahan dan kekuatan atau bakat dan minat untuk mencapai tujuan karir yang sesuai. Bagi siswa SMK, persiapan sebelum menghadapi dunia kerja adalah pendidikan dari sekolah dasar hingga ke perguruan tinggi, lalu sampai tahap ke masa dunia kerja yang penuh persaingan. Oleh karena itu, siswa SMK harus bisa memilih bidang yang sesuai dengan kepribadian diri yang didukung oleh minat dan bakat yang dimiliki.

Pemahaman tentang kepribadian diri sangat penting bagi siswa SMK, merupakan bagian dari informasi dan pemilihan karir. Pengambilan keputusan karir dapat dilakukan karena siswa SMK mampu memahami kepribadian diri sehingga dapat menentukan keputusan untuk studi lanjut atau memilih bekerja. Siswa SMK dapat memahami tentang kepribadian diri melalui tes minat jabatan, dengan mengenali bidang minat, type minat dan tingkat minat maka siswa SMK memiliki informasi dan pilihan karir. Penggunaan tes minat jabatan dapat membantu siswa SMK dalam mengambil keputusan karir. Untuk mengambil keputusan karir, siswa SMK dituntut memiliki pemahaman diri dan memiliki keterampilan pengambilan keputusan karir.

Proses pengambilan keputusan karir adalah suatu proses menentukan pilihan karir dari beberapa alternative pilihan berdasarkan pemahaman diri dan pemahaman karir (Hartono, 2010). Teori pengambilan keputusan karir menekankan adanya penggunaan pengetahuan diri (seperti:bakat, minat dan keterampilan) dan pengetahuan umum (seperti: pekerjaan, penjurusan studi, tantangan dunia kerja, dll) dapat dijadikan sebagai pertimbangan dalam pengambilan keputusan karir (yowell, katz, reardon \& Peterson, 2012). Siswa perlu mengenali diri dan lingkungannya dalam melakukan pengambilan keputusan karir yang didasarkan pada proses berpikir yang diawali dengan pemahaman tentang diri dan lingkungan kerja, sehingga ketika pengambilan keputusan karir dapat berkomitmen untuk melaksanakan keputusan yang diambilnya.

Mengumpulkan dan memproses informasi karir tentang diri dan lingkungannya (terkait eksplorasi dan pengambilan keputusan karir) sebagai hal penting dalam proses pengembangan karir dan penyusunan konstruksi karir terutama bagi siswa SMK yang tengah mengalami transisi menuju persiapan dunia karir yang sesungguhnya (Hartung, 2015). Keseluruhan proses pengumpulan 
informasi karir menurut siswa menggunakan kemampuan kognisi atau proses berpikir, salah satunya dengan bantuan tes minat jabatan yang nantinya hasil tes tersebut dapat memberikan banyak informasi terkait dengan minat dan bakat yang dimiliki siswa SMK.

Dalam membantu siswa memahami hasil tes minat jabatan maka diperlukan adanya proses bimbingan dari guru BK untuk memberikan kejelasan dan informasi tindak lanjut dari hasil tes tersebut. Bimbingan diselenggarakan untuk membantu mengoptimalkan perkembangan siswa, salah satunya pengambilan keputusan karir. Kemampuan pengambilan keputusan karir siswa dapat diupayakan melalui program bimbingan karir. Bimbingan karir adalah suatu proses bantuan, layanan dan pendekatan terhadap siswa SMK, agar siwa yang bersangkutan dapat mengenal dirinya, memahami dirinya dan mengenal dunia kerja, merencanakan masa depannya, dengan bentuk kehidupan yang diharapkannya, untuk menentukan pilihannya, dan mengambil suatu keputusan bahwa keputusan adalah yang paling tepat sesuai dengan keadaan dirinya dihubungkan dengan persyaratan-persyaratan dan tuntutan pekerjaan dan karir yang dipilihnya (Gani, 1996).

Pelaksanaan layanan karir dapat dilakukan secara kelompok, dengan menggunakan kelompok-kelompok kecil memungkinkan bagi siswa untuk dapat saling tukar pendapat. Layanan bimbingan kelompok adalah layanan yang memungkinkan sejumlah peserta didik secara bersama-sama memperoleh bahan dari nara sumber tertentu (guru BK atau konselor) yang berguna untuk menunjang diskusi kelompok serta untuk pertimbangan dalam pengambilan keputusan (Sukardi, 2000). Menurut Prayitno (1995) bahwa bimbingan kelompok adalah kegiatan yang dilakukan oleh sekelompok orang dengan megikut sertakan seluruh anggotanya untuk saling berinteraksi, bebas mengeluarkan pendapat,menanggapi, memberi saran, dan lain sebagainya. Apa yang dibicarakan itu semuanya bermanfaat untuk diri peserta dan peserta lainnya.

Salah satu cara memberikan informasi dan pemahaman karir melalui bimbingan kelompok dengan teknik diskusi dimana siswa satu sama lain siswa saling mendapatkan masukan, saran dan menerima masukan dari peserta kelompok lainnya dalam melakukan pengambilan keputusan karir. Dengan bimbingan kelompok dengan teknik diskusi diharapkan peserta kelompok yaitu siswa SMK dapat memiliki pemahaman dan pengertian dari informasi hasil tes minat jabatan maka siswa SMK mampu melakukan pengambilan keputusan karir 
untuk melanjutkan studi dengan melakukan pemilihan jurusan yang tepat atau akan melakukan pemilihan untuk bekerja setelah lulus SMK.

\section{B. Pembahasan}

\section{Pengertian Pengambilan Keputusan Karir}

Menurut Tiederman dan 0'Hara dalam Sharf (2005) menjelaskan bahwa "membuat keputusan karir adalah upaya untuk membantu individu menyadari semua factor yang melekat pada setiap individu dalam mengambil keputusan, sehingga mampu membuat pilihan yang tepat didasari oleh pengetahuan tentang diri dari informasi eksternal yang sesuai dengan kebutuhan. Keputusan karir merupakan proses pencapaian tujuan karir, yang ditandai oleh adanya: tujuan yag jelas setelah menyelesaikan pendidikan, cita-cita yang jelas terhadap pekerjaan, motivasi terhadap pendidikan, dan pekerjaan yang dicitacitakan, persepsi yang realistis terhadap diri maupun lingkungan, kemampuan pengelompokkan pekerjaan yang diminati, menghargai pekerjaan yang nilai-nilai dalam perilaku positif, kemandirian dalam proses pengambilan keputusan, kematangan dalam proses pengambilan keputusan dan menunjukkan cara-cara realistis dalam mencapai cita-cita pekerjaan.

\section{Kesulitan Pengambilan Keputusan Karir}

Siswa yang mengalami kesulitan dipengaruhi oleh beberapa factor, antara lain: Kurangnya motivasi, tidak memiliki keyakinan diri dan tidak tegas dalam mengambil sikap, Kurangnya informasi terkait pekerjaan, diri sendiri dan bantuan yang ada. Factor internal dan eksternal. Siswa yang mengalami kesulitan Pengambilan Keputusan Karir, menurut Gati, Amir \& Landman (2010) mengakibatkan siswa berperilaku: a) Tidak mau memproses pengambilan keputusan karir, lebih menggantungkan pada pilihan dan keingnan orang lain, b) Menghentikan proses pengambilan keputusan sebelum dicapai suatu keputusan. Dan menjalankan keputusan tersebut tidak dengan pemahaman dan pengertiannya, c) Keputusan yang diambil tidak bisa optimal. Karena keputusan yang diambil tidak didasari pada pengetahuan dan pemahaman yang matang, sehingga melakukannya hanya menjalankan saja tidak dengan pertimbangan dan perencanaan diri.

\section{Hambatan dalam melakukan Pengambilan Keputusan Karir}


Menurut Gati \& Amir (2010), adapun hambatan-hambatan yang membuat siswa mengalami kesulitan dalam pengambilan keputusan karir, adalah: a) LR (lack of readiness) kurangnya motivasi dan keyakinan dalam kesiapan siswa terlibat dalam proses pengambilan keputusan karir, b) LI (lack of information) kurangnya informasi karir (tentang diri sendiri, tahapan dalam proses dan sumber slternative untuk mendapatkan informasi tambahan), c) II (inconsistent information) informasi yang tidak konsisten (informasi yang tidak dapat diandalkan, adanya konflik internal dan eksternal).

Ketiga jenis kesulitan tersebut menghambat dari sebelum proses dan selama proses pengambilan keputusan karir.

\section{Faktor yang mempengaruhi Pengambilan Keputusan Karir}

Ada beberapa factor yang mempengaruhi pengambilan keputusan

karir, salah satu teori karir Krumboltz yang mengajarkan teori belajar social oleh Bandura. Krumboltz menganggap bahwa ada dua factor utama sebagai penentu dalam keputusan karir, yaitu factor pribadi dan lingkungan. Menurut Basori (2004) factor yang harus diperhatikan dalam proses pengambilan keputusan karir adalah, Lingkungan yang dimaksud adalah lingkungan kerja, syarat kerja , nilai kehidupan masyarakat dan kesempatan mendapatkan pekerjaan. Factor pribadi adalah tipe kepribadian, bakat dan kemampuan yang menonjol, minat terhadap suatu jabatan/ pekerjaan, nilai kehidupan pribadi dan hobi/ kesenangan.

\section{Bimbingan Kelompok dengan teknik Diskusi}

\section{1) Pengertian Bimbingan Kelompok}

Menurut Nurihsan (2009) bahwa bimbingan kelompok merupakan bantuan terhadap individu yang dilaksanakan dalam situasi kelompok. Bimbingan kelompok dapat berupa penyampaian informasi ataupun aktivitas kelompok membahas masalah pendidikan, pekerjaan, pribadi dan social. Bimbingan kelompok kaitanya dengan pemahaman eksplorasi karir yaitu siswa dalam situasi kelompok memperoleh bantuan berupa kemudahan dalam menyelesaikan permasalahan terkait dengan kurangnya pemahaman eksplorasi karir pada siswa. Teknik diskusi adalah suatu cara membimbing lewat kelompok, dengan memberi kesempatan pda siswa untuk dapat mengutarakan pendapatnya, menyimpulkan 
mengenai suatu permasalahan atau menyusun berbagai alternative pemecahan pada suatu permasalahan yan dihadapi. Diskusi melibtkan semua anggota kelompok diikutsertkan secara aktif dalam mencapai kemungkinan pemecahan masalah secara bersama-sama mengutarakan maslahnya, mengutarakan ide-ide, mengautarakan saran saling menanggapi setiap peserta dalam rangke pemecahan masalah secara bersama-sama.

\section{Tujuan Pelaksanaan Bimbingan Kelompok}

Melalui layanan bimbingan kelompok dengan teknik diskusi kelompok, para siswa dapat diajak untuk bersama-sama mengemukakan pendapat tentang pengambilan keputusan karir, dan membicarakan topik-topik penting, mengembangkan nilai-nilai dan mengembangkan langkah-langkah bersama untuk menangani permasalahan pengambilan keputusan karir secara kelompok dengan diskusi bersama kelompok.

Menurut Romlah (2006) tujuan penggunaan diskusi kelompok antara lain: a) Menanamkan/ mengembangkan keterampilan dan keberanian untuk mengemukakan pendapat sendiri secara jelas dan terarah; (b) Mencari kebenaransecara jujur melalui pertimbangan-pertimbangan pendapat yang mungkin saja berbeda yang satu dengan yang lainnya; (c) Belajar menemukan kesepakatan pendapat melalui musyawarah karena masalahnya telah dimengerti dan bukankarena paksaan atau terpaksa menerima karena kalah dalam pemungutan suara;(d) Para siswa mendapat informasi yang berharga dari temantemannya dalamdiskusi kelompok dan pembimbing diskusi.

Menurut TIM MKDK (1991), tujuan diskusi kelompok adalah sebagai berikut: (a) Memberi kesempatan kepada setiap peserta untuk mengambil suatu pelajaran dari pengalaman-pengalaman teman-teman peserta yang lain dalammencari jalan keluar suatu masalah; (b) Memberikan suatu kesadaran bagi setiap peserta bahwa setiap orang itu mempunyai masalah sendiri-sendiri; (c)Mendorong individu yang tertutup dan sukar mengatakan masalahnya untuk berani mengutarakan masalahnya; (d) Kecenderungan mengubah sikapsikap dan tingkah laku tertentu setelah mendengarkan pandangan, kritikan atau saran dariteman anggota kelompok. Berdasarkan beberapa pendapat di atas dapat disimpulkan bahwa tujuan diskusi kelompok adalah untuk mengmbangkan kesadaran tentang diri sendiri dan orang lain, mengembangkan keterampilan dan keberanian untuk mengemukakan pendapat, mendapat informasi dari temanteman dan pemimpin diskusi,memberikan suatu kesadaran bagi setiap peserta 
bahwa setiap orang mempunyai masalah sendiri-sendiri, kecenderungan mengubah sikap-sikap tertentu setelahmendengarkan pandangan dan saran dari anggota kelompok.

\section{Tahapan dalam Bimbingan Kelompok}

Terdapat empat tahapan yang harus dilaksanakan dalam diskusi kelompok, tahapan tersebut adalah:

\section{2) Tahap Pembentukan}

Pada tahapan ini terdapat berbagai kegiatan yang akan dilakukan oleh pemimpin kelompok sebagai pengatur sekaligus pelaksana diskusi kelompok. Diantaranya yaitu mengungkapkan pengertian dan tujuan dari kegiatan bimbingan kelompok itu sendiri, menjelaskan mengenai cara-cara pelaksanaan bimbingan kelompok melalui diskusi kelompok, dan juga mengenai asas-asasnya. Sedangkan tugas anggota pada tahapan ini adalah memperkenalkan diri atau melaksanakan kegiatan permainan dalam rangka menciptakan suasana keakraban antar anggota dan pemimpin kelompok.

\section{3) Tahap Peralihan}

Pada tahapan ini pemimpin kelompok akan menjelaskan kegiatan-kegiatan yang akan ditempuh selanjutnya, penawaran kembali kepada anggota kelompok mengenai kesiapannya dalam mengikuti kegiatan selanjutnya dalam bimbingan kelompok.

\section{4) Tahap Kegiatan}

Dalam pelaksanaan tahapan ini pemimpin kelompok akan mengemukakan suatu masalah atau topik yang akan dibahas secara bersama. Tanya jawab antar anggota kelompok dengan pemimpin kelompok tentang hal-hal yang belum jelas mengenai topik permasalahan yang akan dibahas. Dalam tahapan ini anggota kelompok akan membahas topik secara mendalam dan tuntas.

\section{5) Tahap Pengakhiran}

Pada tahap ini pemimpin kelompok mengemukakan bahwa kegiatan akan segera diakhiri, pemimpin dan anggota kelompok mengemukakan kesan-kesan setelah pelaksanaan bimbingan kelompok, mengungkapkan hasil kegiatan, membahas kegiatan selanjutnya, serta mengemukakan pesan dan harapan. 


\section{Persiapan Penelitian}

Berdasarkan hasil multi stage cluster random sampling, yang dilakukan kepada siswa kelas XI maka didapat 10 orang siswa yang memiliki kemampuan pengambilan keputusan karir terendah. Untuk menentukan subjek penelitian, beberapa kelas dipilih berdasarkan random untuk mewakili beberapa kelas lainnya. Dari hasil random sampling untuk keseluruhan kelas XI yang berjumlah 13 kelas, maka dipilih kelas XI TB1, kelas XI TITL2, kelas XI TPM2 dan kelas XI TGB 1 yang akan mewakili untuk diberikan anget kemampuan pengambilan keputusan karir.

Data siswa yang akan mewakili subjek penelitian untuk siswa kelas XI BB1 : 19 siswa, kelas XI TITL2 : 21 siswa, kelas XI TPM2 : 17 siswa dan kelas XI TGB1 : 17 siswa. Setelah dilakukan pretest kepada 74 siswa kelas XI melalui angket kemampuan pengambilan keputusan karir maka didapat 10 siswa yang memiliki nilai terendah dan berdasarkan informasi dari hasil wawancara bersama guru BK SMK N 1 Klego maka dapat ditetapkan nama-nama siswa yang akan mengikuti kegiatan bimbingan kelompok.

SMK N 1 Klego terletak di jalan Cepresan-Klewor KM. 1,5 Sidorejo, Karangmojo, Klego, Boyolali. SMK N 1 Klego memiliki 5 jurusan, yaitu: a) jurusan Tata Busana dibuka 3 kelas,b) jurusan Teknik Permesinan dibuka 4 kelas, c) jurusan Teknik Gambar Bangunan dibuka 2 kelas, d) jurusan Teknik Instalasi Listrik dibuka 3 kelas, e) jurusan Teknik Konstruksi Batu Beton dibuka 1 kelas

Setiap tahunnya SMK N 1 Klego membuka 13 kelas dan menerima sekitar 330 siswa setiap tahun ajaran baru. Jumlah total siswa yang hampir 900 siswa dari kelas 1, 2 dan 3, dengan jumlah guru sekitar 46 orang baik pegawai negeri maupun guru wiyata. Jam belajar normal 5 hari, dimulai dari pukul 07.00 WIB dan diakhiri pukul 15.30 WIB.

\section{Deskripsi Data}

Penelitian ini menggunakan jenis penelitin kuantitatif dengan pendekatan eksperimen menggunakan desain one grup pretest-posttest desaign, yaitu pada desain penelitian ini, dilakukan dengan pre-test sebelum perlakuan diberikan dan post-test sesudahnya, dengan intervensi diskusi hasil tes minat jabatan yang diberikan selama kegiatan bimbingan kelompok. 


\section{Hasil Analisis Deskripsi Pre-Test (Sebelum Perlakuan)}

Hasil analisis statistic deskriptif tentang kemampuan pengambilan keputusan karir sebelum perlakuan (pre-test) pada subjek penelitian dapat dilihat dari table berikut:

Tabel 1

Hasil Uji Statistika

\begin{tabular}{|c|c|}
\hline Hasil Pre-test & $\begin{array}{l}\text { Pengambilan } \\
\text { Keputusan Karir }\end{array}$ \\
\hline N & 10 \\
\hline Mean & 4,4 \\
\hline SD & 2,716 \\
\hline
\end{tabular}

Tabel 1.1

Kategori Tingkat Pengambilan Keputusan Karir Sebelum Perlakuan

\begin{tabular}{|l|c|c|c|c|}
\hline No & Kategori & Kriteria & F & Presentasi (\%) \\
\hline 1 & Tinggi & $>8$ & 1 & $10 \%$ \\
\hline 2 & Sedang & $6-4$ & 5 & $50 \%$ \\
\hline 3 & Rendah & $<3$ & 4 & $40 \%$ \\
\hline Jumlah & & 10 & $100 \%$ \\
\hline
\end{tabular}

Dari table diatas dapat disimpulkan bahwa tingkat kemampuan pengambilan keputusan karir pada siswa SMK N 1 Klego Kelas XI yang mendapat skor tinggi sampai rendah. Ternyata terdapat lebih banyak skor sedang dan rendah daripada skor tinggi, siswa yang memiliki kemampuan pengambilan keputusan karir. 


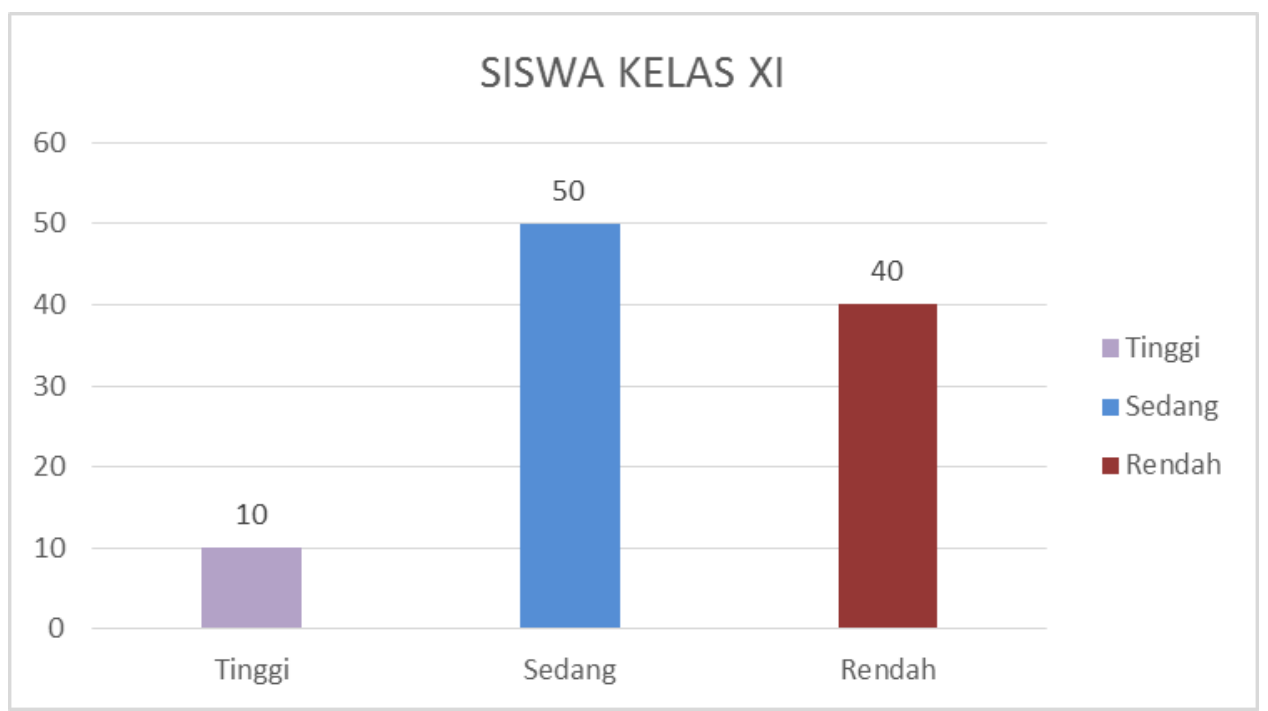

Gambar 1

Diagram sebelum perlakuan (pre-test)

\section{Hasil Analisis Deskripsi Post-Test (Sesudah Perlakuan)}

Hasil analisis statistic deskriptif tentang kemampuan pengambilan keputusan karir sesudah perlakuan (post-test) pada subjek penelitian dapat dilihat dari table berikut:

Tabel 2

Hasil Uji Statistika

\begin{tabular}{|l|l|}
\hline \multicolumn{1}{|c|}{ Hasil Post-test } & \multicolumn{1}{c|}{$\begin{array}{c}\text { Pengambilan } \\
\text { Keputusan Karir }\end{array}$} \\
\hline $\mathrm{N}$ & 10 \\
\hline Mean & 7,6 \\
\hline $\mathrm{SD}$ & 1,713 \\
\hline
\end{tabular}

Tabel 2.1

Kategori Tingkat Pengambilan Keputusan Karir SetelahPerlakuan

\begin{tabular}{|l|l|l|l|l|}
\hline No & \multicolumn{1}{|c|}{ Kategori } & \multicolumn{1}{|c|}{ Kriteria } & \multicolumn{1}{c|}{ F } & Presentasi (\%) \\
\hline 1 & Tinggi & $>9$ & 3 & $30 \%$ \\
\hline 2 & Sedang & $8-6$ & 6 & $60 \%$ \\
\hline 3 & Rendah & $<5$ & 1 & $10 \%$ \\
\hline
\end{tabular}




\begin{tabular}{|l|l|l|l|}
\hline Jumlah & & 10 & $100 \%$ \\
\hline
\end{tabular}

Dari table diatas dapat disimpulkan bahwa perbandingan antara tingkat kemampuan pengambilan keputusan karir pada siswa SMK N 1 Klego Kelas XI yang mendapat skor tinggi dan sedang lebih banyak daripada yang mempunyai skor rendah. Untuk lebih jelas dapat dilihat dari diagram dibawah ini hasil dari post-test (sesudah perlakuan) dengan menggunakan hasil diskusi tes minat jabatan.

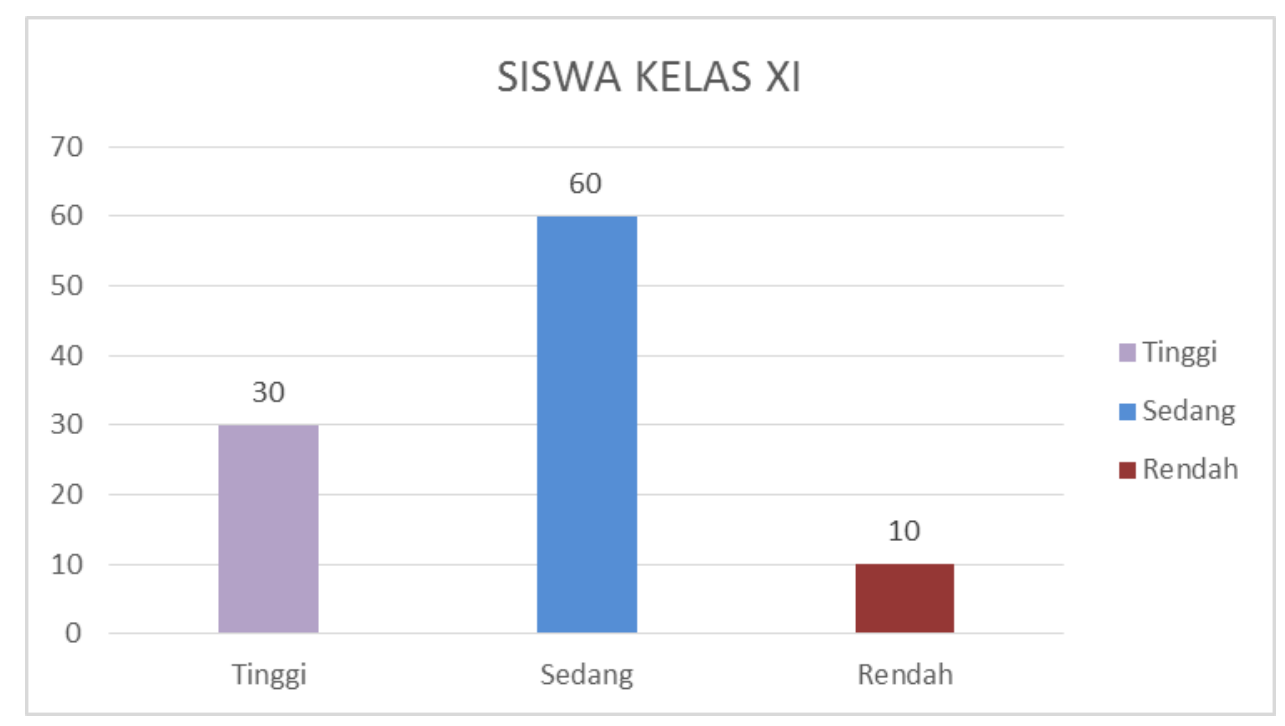

Gambar 2

Diagram sebelum perlakuan (pre-test) dan sesudah perlakuan (post-test)

Dari hasil keseluruhan pre-test dan post-test yang dilakukan untuk mengetahui tingkat kemampuan pengambilan keputusan karir di SMK N 1 Klego. Berikut ini hasil dari setiap siswa yaitu: 


\section{Hasil Pre-test dan Post-test}

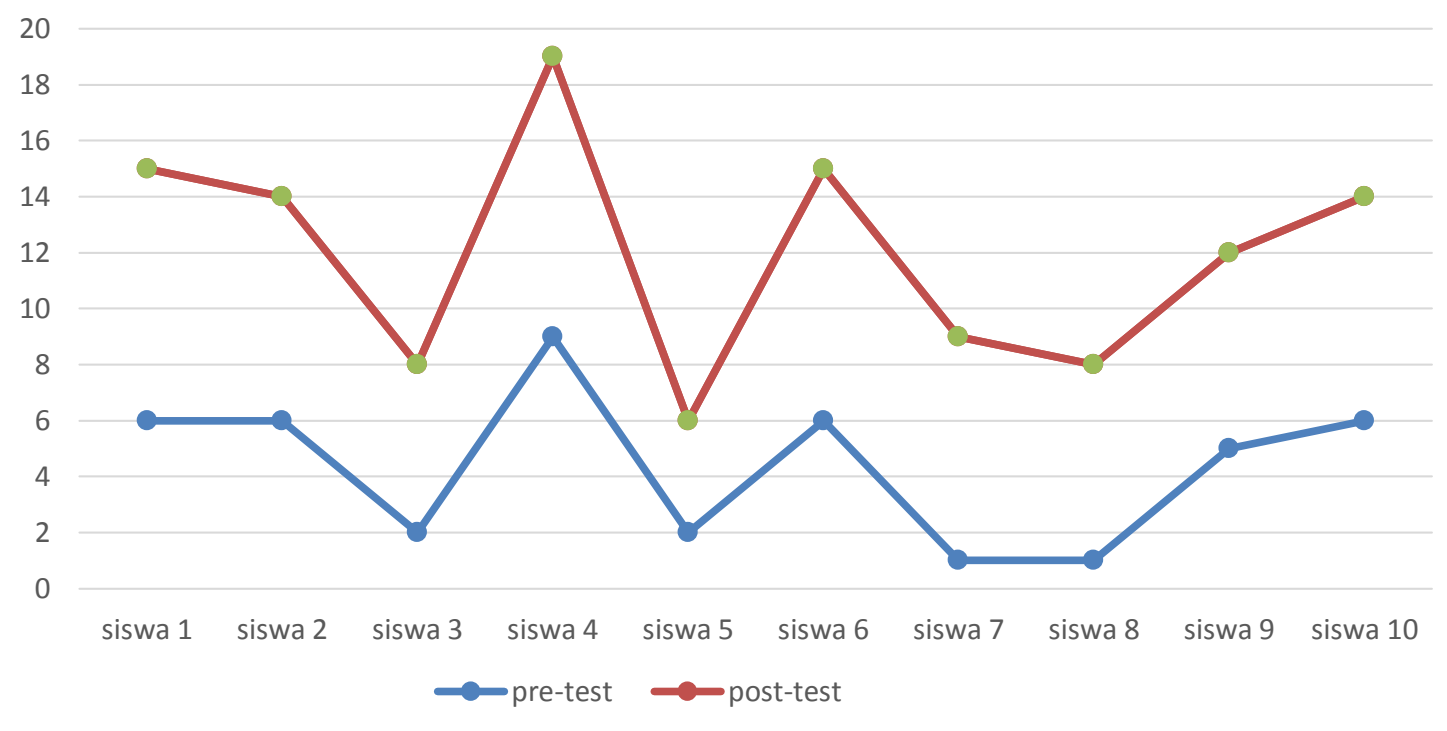

Gambar 3

Hasil Kemajuan setiap anak pada kondisi Pre-Test dan Post-Test

\section{Hasil Penguji Hipotesis}

Penelitian ini dilakukan untuk mengetahui perbedaan sikap siswa sebelum dan sesudah diberikan bimbingan kelompok dengan teknik diskusi melalui hasil tes minat jabatan. Subjek penelitian yang digunakan dalam penelitian ini adalah sejumlah 10 siswa. Kemudian dilakukan pengujian perbedaan sikap siswa dengan menggunakan uji Wilcoxon. Berikut ini adalah data penelitian:

Tabel 3. Data Penelitian

\begin{tabular}{|l|l|l|l|}
\hline Subjek & Pre-test & Post-test & Gain (d) \\
\hline 1 & 6 & 9 & 3 \\
\hline 2 & 6 & 8 & 2 \\
\hline 3 & 2 & 6 & 4 \\
\hline 4 & 9 & 10 & 1 \\
\hline 5 & 2 & 4 & 2 \\
\hline 6 & 6 & 9 & 3 \\
\hline 7 & 1 & 8 & 7 \\
\hline
\end{tabular}




\begin{tabular}{|l|l|l|l|}
\hline 8 & 1 & 7 & 6 \\
\hline 9 & 5 & 7 & 2 \\
\hline 10 & 6 & 8 & 2 \\
\hline$\sum$ & $\mathbf{4 4}$ & $\mathbf{7 6}$ & 32 \\
\hline
\end{tabular}

Pengujian data pada table.3 tersebut menggunakan uji Wilcoxon. Berikut ini adalah hasil pengujian Wilcoxon menggunakan bantuan Software SPSS.20:

Table 3.1 Ujia Wilcoxon Menggunakan SPSS. 20

\begin{tabular}{|l|l|}
\hline Variabel & P-Value \\
\hline Pre tes - Post & 0,005 \\
Tes & \\
\hline
\end{tabular}

Table 3.1 tersebut merupakan uji Wilcoxon menggunakan SPPS.20. dapat diketahui bahwa P-Value uji Wilcoxon tersebut lebih kecil $\alpha(0,05)$ sehingga dapat disimpulkan bahwa terdapat perbedaan sikap pada siswa antara sebelum (pretest) dan setelah (post-test) diberikan bimbingan kelompok.

Tabel Ranks

\begin{tabular}{|l|c|c|c|}
\hline \multicolumn{1}{|c|}{ Ranks } & $\mathrm{N}$ & Mean Rank & Sum \\
\hline Post_test - Pre_test & $0^{\mathrm{a}}$ & .00 & .00 \\
Negative Ranks & & & \\
Positif Ranks & $10^{\mathrm{b}}$ & 5.50 & 55.00 \\
Ties & $0^{\mathrm{c}}$ & & \\
Total & 10 & \\
\hline
\end{tabular}

Tabel. Test Statistics

\begin{tabular}{|l|cc|}
\hline & Post_Test - Pre_Test \\
\hline $\begin{array}{l}\text { Z } \\
\begin{array}{l}\text { Asymp. Sig. (2- } \\
\text { tailed) }\end{array}\end{array}$ & .005 & $2.823^{\mathrm{a}}$ \\
\hline
\end{tabular}



a. $\quad$ Based on negative ranks
b. Wilcoxon Signed Ranks Test

Hipotesis:

$$
\begin{aligned}
& \mathrm{H}_{0} \quad: \mu \mathrm{P}=0 \\
& \mathrm{H}_{\mathrm{A}} \quad: \mu \mathrm{P} \neq 0 \\
& \alpha=0,05
\end{aligned}
$$

Keterangan Pengujian:

Terima $\mathrm{H}_{0}$, Jiika $\mathrm{T}_{\text {hitung }}>\mathrm{T}$ table

Tolak $\mathrm{H}_{0}$, Jiika $\mathrm{T}$ hitung $\leq \mathrm{T}$ tabel

Tabel 3.2 Perhitungan Untuk Uji Wilcoxon

\begin{tabular}{|l|l|l|l|l|l|}
\hline Subjek & Pre-test & Post-test & $\begin{array}{l}\text { Gain } \\
\text { (d) }\end{array}$ & Ranking & Sign \\
\hline 1 & 6 & 9 & 3 & 2,5 & + \\
\hline 2 & 6 & 8 & 2 & 1,5 & + \\
\hline 3 & 2 & 6 & 4 & 4 & + \\
\hline 4 & 9 & 10 & 1 & 1 & + \\
\hline 5 & 2 & 4 & 2 & 1,5 & + \\
\hline 6 & 6 & 9 & 3 & 2,5 & + \\
\hline 7 & 1 & 8 & 7 & 6 & + \\
\hline 8 & 1 & 7 & 6 & 5 & + \\
\hline 9 & 5 & 7 & 2 & 1,5 & + \\
\hline 10 & 6 & 8 & 2 & 1,5 & + \\
\hline$\Sigma$ & $\mathbf{4 4}$ & $\mathbf{7 6}$ & $\mathbf{3 2}$ & & \\
\hline
\end{tabular}

Dari table 2 tersebut didapatkan nilai $\Sigma \mathrm{R}_{+}=27, \Sigma \mathrm{R}_{-}=0, \mathrm{~T}$ hitung $=0$. Kemudian pada $\alpha=0,05$ didapatkan $\mathrm{T}$ table $=8$. Selanjutnya dilakukan perbandingan dan dapat diketahui bahwa $\mathrm{T}_{\text {hitung }}=0$ lebih kecil daripada $\mathrm{T}$ table $=8$, sehinga $\mathrm{H}_{0}$ ditolak dan $\mathrm{H}_{\mathrm{A}}=$ diterima diketahui bahwa Pre Test dan Post Test terdapat perbedaan. 


\section{Pembahasan}

Hasil analisis deskriptif menunjukkan bahwa kedua variable yang diuji. Sebelum pembahasan hasil penelitian, adapun proses serta hasil penelitian secarakeseluruhan adalah sebagai berikut:

Setelah diberikan Pre-Test dan didapat subjek penelitian sebanyak 10 siswa kelas XI di SMK N 1 Klego yang memiliki tingkat kemampuan pengambilan keputusan rendah. Siswa kelas XI sejumlah 10 siswa yang terpilih menjadi subjek penelitian akan diberikan jadwal kegiatan bimbingan kelompok. Setelah siswa kelas XI sejumlah 10 siswa, sebagai subjek penelitian membuat kesepakatan untuk mengikuti kegiatan bimbingan kelompok, maka akan dimulai dengan mengikuti kegiatan tes minat jabatan. Hasil dari tes minat jabatan akan digunakan sebagai bahan diskusi selama kegiatan bimbingan kelompok.

\section{Simpulan}

Dari hasil tes minat jabatan didapat data tentang minat dan tipe kepribadian dari masing-masing subjek penelitian, sehingga dengan hasil tes ini subjek diberikan gamabran utuh tentang jenis-jenis pekerjaan ataupun jurusan bisa ingin melanjutkan studi lanjut. Bimbingan kelompok dengan teknik diskusi memberikan kebebasan kepada setiap subjek untuk menanyakan kesulitan atau kendala yang tengah dihadapi subjek terkait dengan kemampuan pengambilan keputusan karir. Masukan dan saran dari teman-teman memberikan pengalaman bagi subjek yang lain.

Dengan diberikan bimbingan kelompok dengan teknik diskusi memberikan dampak positif kepada siswa, terlihat dari sikap subjek yang mampu memberikan argument tentang rencana masa depannya setelah melihat hasil tes minat jabatan. Dapat diketahui bahwa p-value uji Wilcoxon tersebut lebih kecil $\alpha(0,05)$ sehingga dapat disimpulkan bahwa terdapat perbedaan sikap subjek penelitian antara sebelum (pre test) dan setelah (post test) diberikan bimbingan kelompok dengan teknik diskusi melalui hasil tes minat jabatan.

Dari hasil hipotesis terlihat adanya signifikasi antara sebelum perlakuan dan sesudah perlakuan dengan uji-t statistic. Sehingga terdapat pengaruh kegiatan bimbingan kelompok dengan teknik diskusi melalui hasil tes minat jabatan. Siswa kelas XI SMK N 1 KLego menunjukkan hasil yang baik setelah dilakukan perlakuan terhadap subjek terlihat dari hasil Thitung = lebih besar daripada Ttabel. 
Berdasarkan analisis peneliti dengan bimbingan kelompok teknik diskusi melalaui hasil tes minat kabatan dapat meningkatkan kemampuan subjek untuk melakuan pengambilan keputusan karir. Subjek mendapatkan informasi tentang studi lanjut ataupun memilik pekerjaan, berdasarkan informasi dari hasil tes minat jabatan. Subjek memiliki informasi terkait tipe kepribadian yang sesuai dengan model pekerjaan yang tepat. Siswa memiliki informasi tentang jenis-jenis jurusan dalam melakukan pengambilan keputusan studi lanjut. Dengan memiliki wawasan tentang karir dan informasi tentang tipe kepribadian subjek, diharapkan subjek telah memiliki kepercayaan diri dan mampu merencanakan masa depannya. 


\section{DAFTAR PUSTAKA}

Basori, Muh. 2004. Paket Bimbingan Perencanaan dan Pengambilan Keputusan Karir Bagi siswa SMU. Malang: Universitas Negeri Malang

Gani. A. Ruslan. 1996. Bimbingan Karir. Bandung: PT. Angkasa

Gati, I., Amir, T., \& Landman, S. (2010). Career counsellors' perceptions of the severity of career decision-making difficulties. British Journal of Guidance \& Counselling, 38(4), 393-408. oi:10.1080/03069885.2010.503700

Hartono. 2010. Bimbingan karier bantuan computer untuk siswa SMA Surabaya: UNIPA.

Hartung, P. J. 2015. Life design in childhood: Antecedents and advancement. In L. Nota \& J. Rossier (Eds.), Handbook of life design: From practice to theory and from theory to practice (pp. 89-102). Boston, MA: Hogrefe University Press.

Nurihsan, 2009 Nurihsan, Achmad Juntika. (2009). Bimbingan \& Konseling dalam Berbagai Latar Kehidupan. Bandung: PT Refika Aditama.

Prayitno. 1995. Layanan Bimbingan dan Konseling Kelompok: Dasar dan Profil. Jakarta: Ghalia Indonesia.

Romlah, 2006 Romlah, Tatiek. (2006). Teori dan Praktek Bimbingan Konseling. Malang: Universitas Negeri Malang.

Sharf. 2005. Applying Career Development Theory of Counseling. California: Wadswort,inc.

Sukardi, D. Ketut. 2007. Bimbingan Karier di Sekolah-sekolah. Jakarta: Ghalia.

Tim MKDK. 1991.Bimbingan dan Penyuluhan. Surabaya: university Press IKIP

Yowell, B.E., Kats, P.S., Reardon, C.R., \& Peterson, W.G. .2012. The Role of Negative Career Thinking and Career Problem-Solving Self-Efficacy in Career Exploration Behavior, The Professional Counselor, 2(2), 102-114. 